\title{
Francoise Sylvos, Le Hugo de Balzac dans les Lettres à Madame Hanska
}

\section{Philippe Andrès}

\section{(2) OpenEdition}

10 Journals

\section{Édition électronique}

URL : http://journals.openedition.org/studifrancesi/33401

DOI : 10.4000/studifrancesi.33401

ISSN : 2421-5856

Éditeur

Rosenberg \& Sellier

\section{Édition imprimée}

Date de publication : 1 décembre 2005

Pagination : 661

ISSN : 0039-2944

\section{Référence électronique}

Philippe Andrès, «Francoise Sylvos, Le Hugo de Balzac dans les Lettres à Madame Hanska », Studi

Francesi [En ligne], 147 (XLX | III) | 2005, mis en ligne le 30 novembre 2015, consulté le 19 avril 2021.

URL : http://journals.openedition.org/studifrancesi/33401 ; DOI : https://doi.org/10.4000/

studifrancesi.33401

Ce document a été généré automatiquement le 19 avril 2021.

\section{(c)}

Studi Francesi è distribuita con Licenza Creative Commons Attribuzione - Non commerciale - Non opere derivate 4.0 Internazionale. 


\title{
Francoise Sylvos, Le Hugo de Balzac dans les Lettres à Madame Hanska
}

\author{
Philippe Andrès
}

\section{RÉFÉRENCE}

FRANCOISE SYLVOS, Le Hugo de Balzac dans les Lettres à Madame Hanska «Revue de l'Aire», $\mathrm{n}^{\circ} 27$, hiver 2001, pp. 237.

1 Dans cette étude à problématique intertextuelle, il est question des relations entre Hugo et Balzac à travers leurs échanges épistolaires. On peut s'en douter, la réciprocité n'est pas de mise. Balzac demeure aux yeux de Hugo un «écrivain révolutionnaire». Hugo exerce sur Balzac un pouvoir de fascination, objet d'une rivalité jalouse. Françoise Sylvos rappelle brièvement les rapports commerciaux entre les deux écrivains, à l'époque où Balzac est imprimeur. Les extraits de lettres soulignent une ambivalence qui use de l'ironie pour chacun des auteurs, mais tous deux se retrouveront défenseurs des gens de lettres, notamment à propos des nombreuses contrefaçons. Hugo soutiendra le Vautrin de Balzac, qui, en retour, se désistera à son profit pour un siège à l'Académie française (1839). C'est à propos de l'esthétique dramatique que l'opposition entre les deux hommes semble la plus farouche, et Balzac ne se prive pas d'une critique violente contre Les Burgraves, qui dépasse la simple animosité jalouse. Pour Balzac, il est urgent de proposer un théâtre plus adapté aux exigences d'un public moderne qui ne supporte plus, dans les années quarante, le drame romantique. Cet article, enrichi en annexe d'une lettre d'Hugo en exil, à l'occasion de la mort de Balzac, nous invite à voir les grands hommes par le petit bout de la lorgnette épistolaire et les rend plus humains. 